\title{
SPATIAL PATTERNS OF SPECIES DISTRIBUTIONS IN GRAZED \\ SUBALPINE GRASSLANDS
}

\author{
KOMAC, B. ${ }^{1,2} *$, ALADOS, C. L. ${ }^{1}$ BUENO, C. G. ${ }^{3}$ and GOMEZ, D. ${ }^{3}$ \\ ${ }^{1}$ Pyrenean Institute of Ecology (CSIC). Avda. Montañana 1005. P. O. Box 13034. \\ 50192 Zaragoza, Spain. \\ ${ }^{2}$ Laboratoire of Alpine Ecology UMR CNRS 5553 University of Savoie 73376 Le \\ Bourget-du-Lac, France \\ ${ }^{3}$ Pyrenean Institute of Ecology (CSIC). Regimiento Galicia s/n. P.O. Box 64. 22700 \\ Jaca (Huesca), Spain
}

*Author for correspondence: telephone: +34976716118; fax: +34976716019; e mail: benjamin@komac.fr

\begin{abstract}
Spatial patterns of species diversity have important influences on the functioning of ecosystems and the effect of livestock grazing on spatial heterogeneity can differ depending on the scale of the analysis. This study examined the effects of grazing on the spatial patterns of species distribution and whether the effects of grazing on the spatial distributions of species vary with the scale of the analysis. Data were collected at three locations in the subalpine grasslands of Ordesa-Monte Perdido National Park and Aísa Valley, Central Pyrenees, Spain, that differed in mean stocking rates. Aspect explained about one-third of the environmental variation in species distribution. In flat
\end{abstract}


areas, spatial variation in species composition varied with grazing intensity at two scales. At a coarse scale (among vegetation patches), grazing promoted patchiness, and among-transect variation in species diversity and grazing intensity were positively correlated. At a fine scale (within vegetation patches), the disruption of the selforganizing processes of the species spatial distributions resulted in a reduction in the long-range spatial autocorrelations of some of the characteristic species and in the homogenization of species spatial distributions. Echinospartum horridum encroachment had a great influence on the effect of grazing on south-facing grassland slopes.

Key words: beta diversity, Detrended Fluctuation Analysis, grazing stocking rates, Information Fractal Dimension, self-organization, spatial patterns. 


\section{INTRODUCTION}

Spatial patterns in vegetation develops due to restricted dispersal (Willson, 1993), clonal reproduction (Silander, 1985), and plant interactions (Schwarz et al. 2003; Grau 2002), which leads to increased heterogeneity through vegetation succession (Cook et al. 2005; Seabloom et al. 2005) or ecological memory (the degree to which an ecological process is shaped by past modifications) (Peterson 2002) contribute to the development of vegetation spatial patterns. Grazing can disrupt the spatial structure of plant communities and alter dominance hierarchies (Alados et al. 2003; Rebollo et al. 2002; Roques et al. 2001), which affects the spatial distribution of diversity and has significant implications for functioning of ecosystems. The perception of how grazing influences the spatial distribution of species can depend on the scale of analysis (Adler et al. 2001; Spiegelberger et al. 2006).

In rangeland ecosystems, grazing can have a significant effect on plant species diversity (Cingolani et al. 2005) and even Darwin (1859) recognized the favourable effect of grazing on grasslands. Commonly, biological diversity is associated with the efficient use of resources and ecosystem resilience (Tilman and Kareiva 1996; Chapin et al. 1997; Walker et al. 1999); however, high diversity is not always associated with ecosystem performance and resilience. Grazing can foster invasions by weeds and lead to a reduction in the richness of native plants (Hobbs 2001; Prober and Thiele 1995). Until recently, most of the research has focused on phenomena at a local scale, e.g., resource availability, productivity, biotic interactions, and disturbance (Huston 1979; Huston 1994; Grace 1999; Tilman 1988), and the effect of grazing on the spatial distribution of diversity at multiple spatial scales has not been investigated. Today, however, there is considerable interest in the effects of regional phenomena (Ricklefs 
1987; Huston 1999); e.g., species pools (Zobel 1997) on community composition and biodiversity.

Herbivores can affect the habitat and influence species distributions (Gomez 2005) by increasing or decreasing heterogeneity, which depends on the pre-existing spatial pattern of vegetation and the spatial distribution of grazing (Adler et al. 2001). Grazers interact with vegetation selectively (WallisDeVries et al. 1999), which creates disturbances and gaps (Steinauer and Collins 2001) that can contribute to high spatial heterogeneity (Brown and Allen 1989), particularly evident in subalpine grasslands, where a thick grassland cover can impair seed germination. Through the consumption of biomass and trampling, grazing can increase spatial heterogeneity (Alados et al. 2004; de Bello et al. 2007; Bakker et al. 2003) by creating a mosaic of patches, which increases heterogeneity in these grasslands (Bakker et al. 2003). Typically, however, in arid and semiarid ecosystems (Alados et al. 2003; Alados et al. 2005; Alados et al. 2004), grassland prairies (Collins and Smith 2006; Chaneton and Facelli 1991), and subalpine grasslands (Alados et al. 2007), grazing is an homogenizing process. Livestock can be significant contributors to the dispersal of many plant species (Fisher et al. 1996), when they move between habitat patches during their daily movements and increase the similarity in species composition among fragments (Pueyo et al. 2008). To gain a better understanding of how grazing influences plant spatial patterns at multiple scales, we performed a measurable experiment to examine the spatial patterns of diversity in subalpine grasslands of the Central Pyrenees, Spain, where grazing pressure and topography were variable. We assessed the spatial contribution of species diversity by partitioning vascular plant diversity into their spatial components (Lande 1996; Wagner 2000) and evaluated whether the observed diversity partitions deviated from the null hypothesis because of non-random patterns of intraspecific aggregation 
(Crist et al. 2003). Non-random distributions within species reflects the influence of processes such as environmental filtering acting by the selection of species pool adapted to specific habitats (Grime 1979; Huston 1979; Wassenaar et al. 2005; de Bello et al. 2009). In addition, self-structuring processes such as species modulation, which can alter soil structure and the redistribution of nutrients (Rietkerk et al. 2004; Rietkerk et al. 2002; Meron et al. 2004; Gilad et al. 2004) or niche differentiation and facilitation interactions, can produce an increase in local assemblages and a reduction in random spatial distributions (Venail et al. 2008).

When evaluated at a coarse scale (inter-patch variation; i.e., communities separated by other communities or by bare soil), we predicted an increase in heterogeneity and spatial variation in species composition because of the large turnover in the secondary succession of subalpine grasslands after grazing disturbance (Hawkes and Sullivan 2001; Proulx and Mazumder 1998). At fine scale (intra-patch variation), we predicted that grazing disrupted the structure of the community and favoured the invasion of early successional species, which spread randomly in the landscape and lead to the homogenization of species distributions.

Specifically, we addressed the following questions: (1) Are variation in species composition and distance between sampling sites positively correlated? (2) How does grazing affect the spatial variation in species composition? (3) How does grazing affect the spatial patterns of species distributions?

\section{METHODS}




\section{Study Area}

The study was conducted at two sites in the Central Pyrenees (Spain): the subalpine grasslands of the Ordesa and Monte Perdido National Park (OMPNP) (42 $36^{\circ} \mathrm{N}, 0^{\circ} 00^{\prime}$; from 1700 to $2100 \mathrm{~m}$ a.s.l.; $15608 \mathrm{ha})$ and the Aísa Valley $\left(42^{\circ} 40^{\prime} \mathrm{N}, 0^{\circ} 34^{\text {’W}}\right.$; from 1500 to $1900 \mathrm{~m}$ a.s.l.; 8154 ha). The two areas had similar topography, soils, and climate, and the same grassland plant communities (Aldezabal 2001; Benito Alonso 2006). In the Pyrenees, subalpine pastures are secondary plant communities that have replaced the native forest and have been grazed continuously for at least the last 500 years (Montserrat and Fillat 1990). With the exception of a few annuals that predominate in the gaps created by natural erosion or animal disturbances, most of the plants in the pastures are perennial graminoids and forbs that reproduce clonally. Topography constraints habitat and grazing activity in subalpine ecosystems (GarcíaGonzalez et al. 1990). Flat areas have the highest plant coverage, production, and forage quality, and therefore, are heavily grazed, mainly by cattle (García-Gonzalez et al. 1990; Montserrat and Fillat 1990). Data were collected in the dense pastures of Bromion erecti and Nardion strictae that are between 1800 and 2000 m a.s.l. (García-González et al. 1991; Aldezabal 2001).

Between July and September, the Aísa pastures (1241 ha) were used by 150 cattle and 2000 sheep. The Ordesa site has two pastoral areas, Góriz and Sesa. Góriz (5700 ha) held 6500 ewes and 200 cows. Sesa (1600 ha) held 2800 ewes, 550 cows, and 91 horses (García-Gonzalez et al. 2007; García-González and Marinas, 2008). In terms of LU (livestock unit equivalent to a cow of $500 \mathrm{~kg}$ ) the stocking rate for the different areas was $0.344,0.201$ and $0.603 \mathrm{LU} \mathrm{ha}^{-1}$ year $^{-1}$ respectively, using metabolic weight as conversion system (Heitschmidt and Taylor, 1991). 
Data collection and analysis

To quantify the partitioned components of regional diversity and the influence of environmental and spatial components on the spatial variation of species diversity, in the spring of 2004 we selected two sites in the OMPNP (Góriz and Sesa) and one in the Aísa Valley. At each site, we established nine 250-m linear transects (three on northerly oriented slopes, three on flat areas, and three on southerly exposed sites), reaching a total of 27 transects. In 2005, other nine 250-m linear transects were established at each OMPNP sites (18 in total), where two contrasting grazing pressures and identical physical conditions were present. Aisa Valley was not included in 2005 sampling. In 2004 and 2005, the vegetation was surveyed during the period of peak growth (June and July).

To estimate plant abundance and species richness in each of the transects, we used the Point-Intercept Method (every $20 \mathrm{~cm}$ ) (Goodall 1952) and calculated Shannon and Evenness diversity indices.

(i) Spatial components of species diversity

Vascular plant species diversity was decomposed (following Whittaker 1972) into different spatial components. $\gamma$ diversity is total species diversity in a set of samples, which was partitioned between the average diversity within samples $(\alpha)$ and among samples $(\beta)$; i.e. $\gamma=\alpha+\beta$, (Wagner et al. 2000). In a nested hierarchical design, $\alpha_{\mathrm{i}}$ is the average diversity within samples at level $\mathrm{i}$, and $\beta_{\mathrm{i}}=\alpha_{\mathrm{i}+1^{-}}-\alpha_{\mathrm{i}}$ (Crist et al. 2003; Gering et al. 2003; Lande 1996; Allan 1975; Wagner et al. 2000). We used an hierarchical design that had $\mathrm{i}=1,2$, and 3 nested levels, where level 1 was transect, level 2 was site, and level 3 was Central Pyrenees. 
To test for non-random $\beta$ diversity, we performed a standard randomization routine (Manly 2007). In each randomization, the frequency distribution of each species and the distribution of sampling effort of the empirical data were maintained (Freestone and Inouye 2006). Using Matlab 7.01 software, the randomization models were performed at two levels (Crist et al. 2003): sample-based randomizations (samples are randomized at each hierarchical level) and individual-based randomizations (randomization occurs at the individual level, only), and each randomized data set was partitioned into $\alpha$ and $\beta$ components at each hierarchical level (Crist et al. 2003). Individual-sample randomizations are useful for determining the effect of individual aggregation on the partitioning of diversity and sample-based randomizations reveal how different patches contribute to regional diversity.

(ii) Factors influencing spatial variation in species diversity To calculate the influence of the environmental variables and spatial components on the variance in community composition, we applied canonical partitioning (Legendre et al. 2005; Borcard et al. 1992; Borcard et al. 2004; Legendre and Legendre 1998). We decomposed the variance observed in the response variable $\mathbf{Y}$ (community composition data) as a function of a set of environmental variables $\mathbf{X}_{\mathbf{1}}$ (proportion of bare soil, grazing pressure, and aspect) and a set of spatial variables $\mathbf{X}_{2}$ (X and $\mathrm{Y}$ geographical coordinates). To calculate the partitioning of the spatial and environmental components of the variation in community composition, we used canonical redundancy (RDA) (Rao 1964) in the Ginkgo Analysis System (Bouxin 2005) (http://biodiver.bio.ub.es/vegana/). To generate the dissimilarity matrix among sites, the Euclidean distances were calculated (Krebs 1999). To calculate the correlation between the species dissimilarities of communities and the distance between transects, we used a Mantel Test (Legendre 
and Legendre 1998) using Ginkgo Analysis System (Bouxin 2005). The distance between transects were calculated based on GPS coordinates.

\section{(iii) Spatial patterns of species distribution}

The Information Fractal Dimension ( $\mathrm{D}_{\mathrm{I}}$ ) quantifies the homogeneity of a species distribution. The higher the $\mathrm{D}_{\mathrm{I}}$, the more homogeneous is the distribution. We calculated D I $D_{I} \cong \lim _{\varepsilon \rightarrow 0} \frac{H^{\prime}(\varepsilon)}{\ln 1 / \varepsilon}$, (Farmer et al. 1983), where $H_{(\varepsilon)}^{\prime}$ changes with window size $(\varepsilon)$ following the equation $H_{(\varepsilon)}^{\prime}=\sum_{i=1}^{N_{(\varepsilon)}} p_{i} \ln \frac{1}{p_{i}}$, where $p_{i}$ is the proportion of the intercepts attributed to plant species $i$, which depends on the length of the transect segment (window size $=\varepsilon)$. We selected scales of size $\varepsilon=2^{\mathrm{n}}$, for $\mathrm{n}=0$ to 6 ; i.e., $1,2,4 \ldots 64 \mathrm{~m}$. $D_{I}$ is equivalent to the $z$ exponent of the species-area relationship $S_{(A)}=c\left(\frac{1}{A}\right)^{-z}$ (Rosenzweig 1995), where $\varepsilon$ is equivalent to $1 / \mathrm{A}$ and $\mathrm{S}_{(\mathrm{A})}$ is equivalent to the number of boxes $\mathrm{N}_{(\varepsilon)}$ of the box-counting fractal dimension equation $N_{(\varepsilon)} \cong \varepsilon^{-D}$ (Borda-de-Agua et al. 2002). For the box-counting fractal dimension, each box is either occupied or unoccupied, and the relative occupancy of points inside the box is not considered. $\mathrm{D}_{\mathrm{I}}$ is more precise than $\mathrm{D}$ (Farmer et al. 1983; Alados et al. 1999) because take into consideration the proportion of box occupied.

To detect intrinsic changes in the control mechanisms, we used Detrended Fluctuation Analysis (DFA) to distinguish between spatial patterns caused by pre-existing environmental heterogeneity and those caused by self-organizing processes. DFA measures the degree of spatial autocorrelation in each species' cover, independent of the scale of measurement (Peng et al. 1992; see also Alados and Weber 1999). We calculated the long-range spatial autocorrelations of the vegetated and non-vegetated 
patches, and of each species, individually. In the DFA, the integrated sequence $y(s)=\sum_{i}^{S} x(i)$ was subdivided into non-overlapping sequential sets or 'boxes' of size $b$ $(x(i)=+1$ for presence, $x(i)=-1$, for absence). The long-range spatial autocorrelations of individual species were obtained from the presence $(+1)$ and absence $(-1)$ data of each species. A regression line was fit to each box of size $b$; i.e., $y_{b}(s)$ was regressed on $s$, and the residual variance per each box size was calculated, $F^{2}(b)=\frac{\sum\left(y_{b}(s)-\hat{y}_{b}(s)\right)^{2}}{N}$. To provide the scale of the relationship, $F_{(b)} \propto b^{\rho}$, that process was repeated for scales 4, 6, 8 ... 256 points along the first 1025 points of each transect. Following Halley et al. (2004), we chose a minimum scale that was greater than the minimum species crown diameter (inter-point separation) and a maximum inter-point distance (coarse resolution) of one-quarter of the set diameter. The DFA exponent reflects the long-range correlation of the plant distribution sequence, which is equivalent to the Hurst Exponent (Hausdorff et al. 1997), but it is a superior method for quantifying long-range correlations (Hu et al. 2001; Taqqu et al. 1995). Long-range power-law correlations cannot be analyzed using correlation analyses because they are non-stationary. DFA exponents can detect the long-range correlations that are embedded in seemingly non-stationary sequences and remove trends that can arise from fluctuations in external factors, e.g., soil structure. Theoretically, the DFA exponent is not affected by the magnitude of the fluctuations, but by the sequential ordering of the fluctuations. Among the 13 species evaluated in this study, only five showed significant correlations between cover and rho values. When $\rho=1 / 2$, the sequence is randomly distributed, but when $\rho>1 / 2$, the sequence depends on the history of the distribution. An area in which $\rho$ is larger than in another area indicates greater non-randomness and, therefore, is evidence of higher structural self-organization. 


\section{RESULTS}

Spatial components of species diversity

In the subalpine grasslands of Central Pyrenees, we recorded 156 species of plants from 37 families, of which 108 were forbs, 22 were graminoids, 11 were dwarfs, 10 were shrubs, and one was a tree. Only $19(12 \%)$ of the species occupied $>1 \%$ of plant covered.

The additive partitions of the Shannon Index indicated that $\alpha_{1}$ diversity accounted for $76 \%$ of the regional diversity, and only $8 \%$ was attributed to among-transect variation $\left(\beta_{1}\right)$. Among-site variation $\left(\beta_{2}\right)$ accounted for $15 \%$ of the regional diversity (Table 1$)$. The observed levels of $\beta_{1}$ diversity were significantly lower than the values expected based on the individual-based randomizations $(\mathrm{t}=-4.51$, $\mathrm{df}=16, \mathrm{P}<0.001)$. Amongsite diversity $\left(\beta_{2}\right)$ did not differ significantly from that expected based on individualbased randomizations $(\mathrm{t}=1.73, \mathrm{df}=16, \mathrm{NS})$.

The Euclidean distance matrix of floristic dissimilarity and the distance between transects were not significantly $\left(r_{s}=0.03\right.$, NS) correlated, which indicates that components other than the spatial component of diversity had an effect on species dissimilarity. The Redundancy Analysis (RDA) revealed that only $29.6 \%$ of the variation in community structure was explained by environmental (grazing pressure, proportion of bare soil, and aspect) (20.8\%) and spatial (X and Y geographical coordinates) $(8.4 \%)$ variables. Aspect $(0=$ flat, $1=$ north, and $-1=$ south $)$ contributed $11 \%$ of the variation explained by the environmental variables. 
Grazing pressure and spatial variation in diversity

Grazing pressure had a significant effect on species richness and diversity on transects that has a southern aspect, but not on transects on flat ground or those that had a northern aspect (Table 2). On south-facing slopes, richness and proportional diversity indices (Shannon and Evenness indices) were significantly positively correlated with grazing pressure. Nineteen of the 156 species in the OMPNP provided $80 \%$ of the vegetative cover. On south-facing slopes, Echinospartum horridum provided 50\% of the vegetative cover under low grazing pressure, but only $11 \%$ on the transects where grazing pressure was high. When the analysis was restricted to the sites on north-facing slopes and on flat ground, the distance between transects and floristic dissimilarity, as measured by Euclidean distance, were significantly correlated $\left(\mathrm{r}_{\mathrm{s}}=0.216, \mathrm{P}<0.01\right)$. Thus, when the effect of aspect was controlled, the spatial component of diversity became more important. Indeed, the average among-transect variation, $\beta_{1}$, at sites on north-facing slopes and on flat ground grouped together, was almost twice as high when grazing pressure was high $(0.290 \pm 0.042)$ as it was when grazing pressure was low $(0.150 \pm 0.045)$. Thus, once the effect of aspect was removed, grazing had a significant effect on spatial diversity in the subalpine grasslands of the Pyrenees.

Grazing pressure and spatial patterns of species distributions

Livestock grazing had a significant effect on the long-range spatial autocorrelations (DFA exponents) of the species in the flat subalpine grasslands. Of the 13 species that occurred at both grazing sites and were present in most of the slope aspects, more than 
half had long-range spatial autocorrelations that were lower where grazing pressure was high than where it was low and, for four of those species, the difference was statistically significant (Table 3). In keeping with the decrease in the long-range spatial autocorrelations of plants with an increase in grazing pressure, the Information Fractal Dimension, $\mathrm{D}_{\mathrm{I}}$ was significantly higher in flat areas (higher homogenous distribution), where the effect of grazing on the spatial distribution of plant species was most evident, than it was at sites that had southern or northern aspects (Table 2).

\section{DISCUSSION}

In the subalpine grasslands of the Central Pyrenees, the spatial variation in diversity reflected the importance of self-organizing mechanisms in the ecosystem. As reported by several studies (Freestone and Inouye 2006; Crist et al. 2003; Gering et al. 2003), among-transect variation $\left(\beta_{1}\right)$ was lower than what was expected based on individualbased randomizations, which reflects the presence of spatial structuring processes. Furthermore, it suggests that multiple mechanisms including spatial heterogeneity, dispersal patterns, and biotic interactions (Bolker and Pacala 1999; Levin 1974; Seabloom et al. 2005) influence the spatial distribution of diversity. Unlike in more highly fragmented ecosystems such as serpentine outcrops (Freestone and Inouye 2006) or the patchy environment of Cabo de Gata National Park (SE Spain) (Alados et al. 2009), in the grasslands of the Central Pyrenees among-site variation $\left(\beta_{2}\right)$ did not differ significantly from what was expected based on individual-based randomizations. Thus, among-site diffusion processes lead to low among-transect variation, which is characteristic of long-lasting, well-established communities that have prolonged periods 
of diffusion (Kareiva 1982). Our results suggest that the traditional grazing practices in the subalpine grasslands of the Central Pyrenees have fostered high connectivity among grassland patches.

Among the factors that influenced the spatial distribution of species, slope aspect explained about one-third of the environmental component of the variation in plant diversity (11\% of $30 \%)$. The spatial component explained only $8 \%$ of the variation in plant diversity when slope aspect was included in the analysis, and floristic dissimilarity and distance between transects were not significantly correlated. In the Central Pyrenees, E. horridum, a thorny-cushion legume, forms large, dense monospecific patches that can cover several hectares in areas where only a few other species persist within the gaps (Alados et al. 2007). The abundance of E. horridum on south-facing slopes subjected to light grazing was dramatic. In heavily grazed grasslands, the abundance of E. horridum was much lower, which promoted the expansion of populations of species that are less sensitive to, or favoured by, grazing; e.g., Festuca rubra, Thymus praecox. When the effect of low grazing pressure on south slopes was removed by removing the data from the south slope from the analyses, the spatial component of diversity was a significant factor in structuring spatial diversity, and species dissimilarity and the distance between transects were significantly, positively correlated. In addition, grazing had a significant effect on spatial diversity in the subalpine grasslands. Among-transect variation was higher in heavily grazed sites than it was in lightly grazed sites.

Grazing can act as a landscape modulator by altering soil structure and the redistribution of nutrients, and can increase heterogeneity through vegetation succession (Cook et al. 2005; Seabloom et al. 2005) or ecological memory (the degree to which an ecological process is shaped by past modifications) (Peterson 2002). Grazing in highly productive 
sites, that have high ability to recolonize vegetation gaps after perturbation, can increase beta diversity (heterogeneity) (Steiner and Leibold 2004; Bakker et al. 2003), which is in contrast to what can occur in less productive sites, as predicted by Steiner and Leibold (2004); i.e., $\beta_{1}$ diversity was higher in the more productive ecosystem (Central Pyrenees, 0.30) than it was in the less productive ecosystem (Cabo de Gata National Park, 0.17) (Alados et al. 2009).

In addition, grazing can create gaps in the thick layer of subalpine perennial grasses and provides an opportunity for colonization by seed-dispersed species (Pakeman and Field 2005), which colonize space randomly (Kershaw 1963; Fowler 1990). In our study, in the flat areas that were subjected to the highest grazing pressures from herbivores, the Information Fractal Dimension $\left(\mathrm{D}_{\mathrm{I}}\right)$ and grazing pressure were positively correlated. As in other studies, grazing increased the homogeneity (high $\mathrm{D}_{\mathrm{I}}$ ) of species’ distributions (de Bello et al. 2007; Collins and Smith 2006; Alados et al. 2003). Moreover, at a fine scale (within patches), grazing disrupted community assemblages, homogenized the spatial distributions of species, and reduced the long-range spatial autocorrelations of half of the most abundant plant species in flat areas. Communities assembled by selforganizing processes such as niche differentiation, allows greater coverage of the heterogeneous environment (Venail et al. 2008), results in an increase in the efficiency of the use of resources (Venail et al. 2008) and the positive effect of plant diversity on primary production (Loreau and Hector 2001). The destruction of the community spatial structure will disrupt the self-organization gene-complex of long standing stable communities. In vitro microcosm experiments have shown that when the community spatial structure is broken by shaking the tubes, diversity is reduced.

In the Central Pyrenees, grazing pressure had a significant effect on the species richness and diversity on transects that has a southern exposure, but not on transects in flat areas 
or on those that had northern exposures. The decline in E. horridum in heavily grazed areas is more closely associated with traditional management practices, such as prescribed fires, than with depredation by livestock. Traditionally, the grasslands in the Central Pyrenees have been burned, but controlled recolonization from seeds by $E$. horridum in the heavily grazed sites has favoured the spread of other plant species. In contrast, a reduction in grazing pressure can favour an increase in the encroachment by E. horridum in lightly grazed sites (Montserrat et al. 1984). In the last $30 \mathrm{yr}$, the abandonment of grazing practices in the Pyrenees has resulted in a 47\% increase in the biomass of woody vegetation (Bartolomé et al. 2005). Thus, heavy grazing after fire, the traditional means of reducing woody plants (Ellenberg 1988; Garcia-Ruiz and ValeroGarces 1998), might be the best practice for maintaining pastures and preventing plant succession in subalpine ecosystems.

We conclude that the spatial structure of subalpine grassland communities in the Pyrenees was altered by grazing, particularly in flat areas, which resulted in an increase in spatial heterogeneity, when evaluated at a coarse scale (among patches), and the homogenization of species distributions at a fine scale (within patches). On south-facing grassland slopes, the reduction of E. horridum as grazing intensity increased influenced significantly the spatial diversity of grasslands. The effects of grazing on subalpine grasslands can operate on at least two scales of analysis: a positive effect at a coarse scale because of an increase in heterogeneity, which increases the opportunity for species to colonize gaps and, thereby, increases diversity, and a negative effect at a fine scale because of a disruption in the spatial organization of the community, which has a detrimental effect on niche complementarity. Further research is needed to determine which of the two processes are more important for the conservation grasslands, or whether equilibrium between the two processes is more advantageous. 


\section{ACKNOWLEDGEMENTS}

We gratefully acknowledge the support of the Spanish CICYT project CGL2005-01131/ BOS. We thank Yolanda Pueyo, Maite Gartzia, Ana Marinas, Beatriz Bueno, and Elena Lahoz for assistance in collecting field data. We thank Bruce MacWhirter for critically reading and providing helpful suggestions on the manuscript. 


\section{REFERENCES}

Adler PB, Raff DA, Lauenroth WK (2001) The effect of grazing on the spatial heterogeneity of vegetation. Oecologia 128:465-479. doi: 10.1007/s004420100737

Alados CL, El Aich A, Komac B, Pueyo Y, García-González R (2007) Self-organized spatial patterns of vegetation in alpine grasslands. Ecol Modeling 201:233-242. doi:10.1016/j.ecolmodel.2006.09.014

Alados CL, Navarro T, Komac B, Pascual V, Martinez F, Cabezudo B, Pueyo Y (2009) Do vegetation patch spatial patterns disrupt the spatial organization of plant species? Ecological Complexity 6:197-207. doi:10.1016/j.ecocom.2008.10.015 Alados CL, El Aich A, Papanastasis VP, Ozbek H, Navarro T, Freitas H, Vrahnakis M, Larrosi D, Cabezudo B (2004) Change in plant spatial patterns and diversity along the successional gradient of Mediterranean grazing ecosystems. Ecol Modelling 180:523535. doi:10.1016/j.ecolmodel.2003.10.034

Alados CL, Escos J, Emlen JM, Freeman DC (1999) Characterization of branching patterns by fractal analyses to detect plant adaptative strategies. Int J Plant Sci 160:S147-S155.

Alados CL, Pueyo Y, Giner ML, Navarro T, Escos J, Barroso F, Cabezudo B, Emlen JM (2003) Quantitative characterization of the regressive ecological succession by fractal analysis of plant spatial patterns. Ecological Modelling 163:1-17. doi:10.1016/S0304-3800(02)00294-6 Alados CL, Pueyo Y, Navas D, Cabezudo B, González A, Freeman DC (2005) Fractal analysis of plant spatial patterns: a monitoring tool for vegetation transition shifts. Biodiversity and Conservation 14:1453-1468. doi: 10.1007/s10531-004-9669-3 
Alados CL, Weber DN (1999) Lead effects on the predictability of reproductive behavior in fathead minnows (Pimephales promelas): a mathematical model. Env Toxicology and Chemistry 18:2392-2399.

Aldezabal A (2001) El sistema de pastoreo del Parque Nacional de Ordesa y Monte Perdido (Pirineo Central, Aragón). Interacción entre la vegetación supraforestal y los grandes herbívoros. Publicaciones del Consejo de Protección de la Naturaleza de Aragón, Zaragoza

Allan JD (1975) Components of diversity. Oecologia 18:359-367. doi: 10.1007/BF00345855

Bakker C, Blair JM, Knapp AK (2003) Does resource availability, resource heterogeneity or species turnover mediate changes in plant species richness in grazed grasslands? Oecologia 137:385-391. doi: 10.1007/s00442-003-1360-y

Bartolomé J, Plaixat J, Fanlo R, Boada M (2005) Conservation of isolated Atlantic heathlands in the Mediterranean region: effects of land-use changes in the Montseny biosphere reserve (Spain). Biological Conservation 122:81-88.

doi:10.1016/j.biocon.2004.05.024

de Bello F, Lepš J, Sebastià MT (2007) Grazing effects on the species-area relationship: variation along a climatic gradient in NE Spain. J Veg Sci 18:25-34. doi: 10.1658/11009233(2007)18[25:GEOTSR]2.0.CO;2

Benito Alonso JL (2006) Vegetación del Parque Nacional de Ordesa y Monte Perdido (Sobrarbe, Pirineo Central Aragonés). Publicaciones del Consejo de Protección de la Naturaleza de Aragón, Zaragoza.

Bolker BM, Pacala SW (1999) Spatial moment equations for plant competition: understanding spatial strategies and the advantages of short dispersal. Am Nat 162:135148. doi: $10.1086 / 303199$ 
Borcard D, Legendre P, Avois-Jacquet C, Guerrero J, Tuomisto H (2004) Dissecting the spatial structure of ecological data at multiple scales. Ecology 85:1826-1832. doi: $10.1890 / 03-3111$

Borcard D, Legendre P, Drapeau P (1992) Partialling out the spatial component of ecological variation. Ecology 73:1045-1055. doi: 10.2307/1940179

Borda-de-Agua L, Hubbell SP, McAllister M (2002) Species-area curves, diversity indices, and species abundance distributions: A multifractal analysis. Am Nat 159:138155. doi: $10.1086 / 324787$

Bouxin G (2005) Ginkgo, a multivariate analysis package. J Veg Sci 16:355-359. doi: 10.1658/1100-9233(2005)016[0355:GAMAP]2.0.CO;2

Brown BJ, Allen TFH (1989) The importance of scale in evaluating herbivory impacts. Oikos 54:189-194.

Chaneton EJ, Facelli JM (1991) Disturbance effects on plant community diversity: spatial scales and dominance hierarchies. Plant Ecol 93:143-155. doi: 10.1007/BF00033208

Chapin FS, Walker BH, Hobbs RJ, Hooper DU, Lawton JH, Sala OE, Tilman D (1997) Biotic control over the functioning of the ecosystems. Science 277:500-504. doi: 10.1126/science.277.5325.500

Cingolani AM, Noy-Meir I, Díaz S (2005) Grazing effects on rangeland diversity: a synthesis of contemporary models. Ecol Applications 15:757-773. doi: 10.1890/03-5272 Collins SL, Smith MD (2006) Scale-dependent interaction of fire and grazing on community heterogeneity in tallgrass prairie. Ecology 87:2058-2067. doi: 10.1890/0012-9658(2006)87[2058:SIOFAG]2.0.CO;2 
Cook WM, Yao J, Foster BL, Holt RD, Patrick BL (2005) Secondary succession in an experimentally fragmented landscape: community patterns across space and time. Ecology 86:1267-1279. doi: 10.1890/04-0320

Crist TO, Veech JA, Gering JC, Summerville KS (2003) Partitioning species diversity across landscapes and regions: a hierarchical analysis of $\alpha, \beta, \gamma$ diversity. Am Nat 162:734-743. doi: 10.1086/378901

Darwin C (1859) The origin of species by means of natural selection. John Murray, London.

Ellenberg H (1988) Vegetation ecology of Central Europe. Cambridge University Press, Cambridge.

Farmer D, Ott E, Yorke JA (1983) The dimension of chaotic attractors. Physica 7D:153180.

Fischer SF, Poschold P, Beinlich B (1996) Experimental studies on the dispersal of plants and animals on sheep in calcareous grasslands. J Appl Ecol 33:1206-1222. Fowler NL (1990) Disorderliness in plant communities: comparisons, causes and consequences. In: Grace JB, Tilman D (eds), Perspectives on plant competition. Academic Press, New York, pp 291-306.

Freestone AL, Inouye BD (2006) Dispersal limitation and environmental heterogeneity shape scale-dependent diversity patterns in plant communities. Ecology 87:2425-2432. doi: 10.1890/0012-9658(2006)87[2425:DLAEHS]2.0.CO;2

García-González R, Gomez D, Remón JL (1991) Application of vegetation maps to the study of grazing utilization: a case in the Western Pyrenees. Phytocoenology 3:251-256. García-Gonzalez R, Hidalgo R, Montserrat C (1990) Patterns of livestock use in time and space in the summer ranges of the western Pyrenees: a case study in the Aragon valley. Mountain Research and Development 10:241-255. 
García-González R, Alados CL, Bueno G, Fillat F, Gartzia M, Gómez, Komac B, Marinas A, Saint-Jean N (2007)Valoración ecológica y productiva de los pastos supraforestales en el Parque Nacional de Ordesa y Monte Perdido. In: Ramírez L Asensio B (eds), Proyectos de investigación en parques nacionales: 2003-2006. Organismo Autónomo de Parques Nacionales, Ministerio de Medio Ambiente, Madrid, pp 105-128.

García-González R, Marinas A (2008) Bases ecológicas para la ordenación de superficies pastorales. In: Fillat F, García-González R, Gómez D, Reiné R (eds), Pastos del Pirineo. Departamento de Publicaciones CSIC, Madrid, pp. 229-253.

Garcia-Ruiz JM, Valero-Garces BL (1998) Historical Geomorphic Processes and Human Activities in the Central Spanish Pyrenees. Mountain Research and Development 18:309-320.

Gering JC, Crist TO, Veech JA (2003) Additive partitioning of species diversity across multiple spatial scales: Implications for regional conservation of biodiversity. Conservation Biology 17:488-499. doi: 10.1046/j.1523-1739.2003.01465.x Gilad E, von Hardenberg J, Provenzale A, Shachak M, Meron E (2004) Ecosystem engineers: from pattern formation to habitat creation. Physical review letters 93:98105. doi: 10.1103/PhysRevLett.93.098105

Gomez JM (2005) Long-term effects of ungulates on performance, abundance, and spatial distribution of two montane herbs. Ecology 75:231-258. doi: 10.1890/04-0722 Goodall DW (1952) Some considerations in the use of point quadrats for the analysis of vegetation. Australian J Sci Research Bulletin 5:1-41.

Grace JB (1999) The factors controlling species density in herbaceous plant communities: an assessment. Perspectives in Plant Ecol, Evolution and Systematics 2:128. doi:10.1078/1433-8319-00063 
Grau HR (2002) Scale-dependent relationships between treefalls and species richness in a neotropical montana forest. Ecology 83:2591-2601. doi: 10.1890/00129658(2002)083[2591:SDRBTA]2.0.CO;2

Grime JP (1979) Plant strategies and vegetation processes. John Wiley and Sons, Chichester.

Halley JM, Hartley S, Kallimanis AS, Kunin WE, Lennon JJ, Sgardelis SP (2004) Uses and abuses of fractal methodology in ecology. Ecol Letters 7:254-271. doi:

10.1111/j.1461-0248.2004.00568.x

Hausdorff JM, Mitchell SL, Firtion R, Peng CK, Cudkowicz ME, Wei JY, Goldberger AL (1997) Altered fractal dynamics of gait: reduced stride-interval correlations with aging and Huntington's Disease. J Appl Physiol 82:262-269.

Hawkes CV, Sullivan JJ (2001) The impact of herbivory on plant in different resource conditions: a meta-analysis. Ecology 82:2045-2058. doi: 10.1890/0012-

9658(2001)082[2045:TIOHOP]2.0.CO;2

Heitschmidt RK, Taylor CA (1991) Livestock Production. In: Heitschmidt RK, Stuth J W (eds), Grazing Management, an Ecological Perspective. Timber Press, Portland, pp $161-177$.

Hobbs RJ (2001) Synergisms among Habitat Fragmentation, Livestock Grazing, and Biotic Invasions in Southwestern Australia. Conservation Biology 15:1522-1528. doi: 10.1046/j.1523-1739.2001.01092.x

Hu K, Ivanov PC, Chen Z, Carpena P, Stanley HE (2001) Effect of trends on detrended fluctuation analysis. Physical Review E 64:1-19. doi: 10.1103/PhysRevE.64.011114 Huston MA (1979) A general hypothesis of species diversity. Am Nat 113:81-101. Huston MA (1994) Biological diversity: the coexistence of species on changing landscapes. Cambridge University Press, Cambridge. 
Huston MA (1999) Local processes and regional patterns: appropriate scale for understanding variation in the diversity of plants and animals. Oikos 86:3393-3401. Kareiva P (1982) Experimental and mathematical analysis of herbivore movement: quantifying the influence of plant spacing and quality on foraging discrimination. Ecol Monogr 52:261-282. doi: 10.2307/2937331

Kershaw KA (1963) Pattern in vegetation and its causality. Ecology 44:377-388. doi: $10.2307 / 1932185$

Krebs CJ (1999) Ecological Methodology (2nd ed.). Addison Wesley Longman, Menlo Park, California.

Lande R (1996) Statistics and partitioning of species diversity, and similarity among multiple communities. Oikos 76:5-13.

Legendre P, Borcard D, Peres-Neto PR (2005) Analyzing beta diversity: partitioning the spatial variation of community composition data. Ecol Monogr 75:435-450. doi: $10.1890 / 05-0549$

Legendre P, Legendre L (1998) Numerical ecology. Elsevier, Amsterdam. Manly BFJ (2007) Randomization, bootstrap and Monte Carlo methods in biology. (3rd ed.). Chapman and Hall, London.

Levin SA (1974) Dispersion and population interactions. Am Nat 108:207-228. doi: $10.1086 / 282900$

Loreau M, Hector A (2001) Partitioning selection and complementarity in biodiversity experiments. Nature 412:72-76. doi:10.1038/35083573

Meron E, Gilad E, von Hardenberg J, Shachak M, Zarmi Y (2004) Vegetation patterns along a rainfall gradient. Chaos, Solitons and Fractals 19:367-376. doi:10.1016/S09600779(03)00049-3 
Montserrat P, Fillat F (1990) The system of grassland management in Spain. In:

Breymeyer AI (ed), Managed Grasslands Regional Studies. Elsevier, Amsterdam, pp $37-70$.

Montserrat P, Montserrat JM, Montserrat G (1984) Estudio de las comunidades de Echinospartum horridum en el Pirineo español. Acta Biologica Montana IV:249-257. Pakeman RJ, Field CB (2005) The role of seed bank, seed rain, and the timing of disturbance in gap regeneration. J Veg Sci 16:121-130. doi: 10.1658/11009233(2005)016[0121:TROTSB]2.0.CO;2

Peng CK, Buldyrev SV, Goldberger AL, Havlin S, Sciortino F, Simons M., Stanley HE (1992) Long-range correlations in nucleotide sequences. Nature 356:168-170.

Peterson GD (2002) Contagious disturbance, ecological memory, and the emergence of landscape pattern. Ecosystems 5:329-338. doi: 10.1007/s10021-001-0077-1

Prober SM, Thiele KR (1995) Conservation of the grassy white box woodlands: relative contributions of size and disturbance to floristic composition and diversity of remnants. Australian J Botany 43:349-366. doi:10.1071/BT9950349

Proulx M, Mazumder A (1998) Reversal of grazing impact on plant species richness in nutrient-poor vs. Nutrient-rich ecosystems. Ecology 79:2581-2592. doi: 10.1890/00129658(1998)079[2581:ROGIOP]2.0.CO;2

Pueyo Y, Alados CL, Barrantes O, Komac B, Rietkerk M (2008) Differences in gypsum plant communities associated with habitat fragmentation and livestock grazing. Ecol Appl 18:954-964. doi: 10.1890/07-1770.1

Rao CR (1964) The use and interpretation of principal component analysis in applied research. Sankhyaá, Series A 26:329-358.

Rebollo S, Milchunas DG, Noy-Meir I, Chapman PL (2002) The role of a spiny plant refuge in structuring grazed shortgrass steppe plant communities. Oikos 98:53-64. 
Ricklefs RE (1987) Community diversity: relative roles of local, regional processes.

Science 235:167-171. doi: 10.1126/science.235.4785.167

Rietkerk M, Boerlijst M, van Langevelde F, HilleRisLambers R, van de Koppel J,

Kumar L, Prins H, de Roos A (2002) Self-organization of vegetation in arid ecosystems. Am Nat 160:524-530. doi: 10.1086/342078

Rietkerk M, Dekker SC, de Ruiter PC, van de Koopel J (2004) Self-orgnized patchiness and catastrophic shifts in ecosystems. Science 305:1926-1929. doi:

10.1126/science.1101867

Roques KG, O'Connor TG, Watkinson AR (2001) Dynamics of shrub encroachment in an Africa savanna: relative influence of fire, herbivory, rainfall and density dependence. J Appl Ecology 38:268-280. doi: 10.1046/j.1365-2664.2001.00567.x

Rosenzweig ML (1995) Species diversity in space and time. Cambridge University Press, Cambridge.

Schwarz PA, Fahey TJ, McCulloch CE (2003) Factors controlling spatial variation of tree species abundance in a forest landscape. Ecology 84:1862-1878. doi: 10.1890/0012-9658(2003)084[1862:FCSVOT]2.0.CO;2

Seabloom EW, Bjørnstad ON, Bolker BM, Reichman OJ (2005) Spatial signature of environmental heterogeneity, dispersal, and competition in successional grasslands. Ecol Monogr 75:199-214. doi: 10.1890/03-0841

Silander JA (1985) Microevolution in clonal plants. In: Jackson JBC, Buss LW, Cook RE (eds), Population Biology and Evolution of Clonal Organisms. Yale University Press, London, pp 107-152.

Spiegelberger T, Matthies D, Müller-Schärer H, Schaffner U (2006) Scale-dependent effects of land use on plant species richness of mountain grassland in the European Alps. Ecography 29:541-548. doi: 10.1111/j.0906-7590.2006.04631.x 
Steinauer EM, Collins SL (2001) Spatial cascades in community structure following urine deposition in tallgrass prairie. Ecology 82:1319-1329.

Steiner CF, Leibold MA (2004) Cyclic assembly trajectories and scale-dependent productivity-diversity relationships. Ecology 85:107-113. doi: 10.1890/03-3010 Taqqu, MS, Teverovsky V, and Willinger M 1995. Estimators for long range dependence: an empirical study. Fractal 3:785-798.

Tilman D (1988) Plant strategies and the dynamics and structure of plant communities. Princeton University Press, Princeton.

Tilman D, Kareiva P (1996) Biodiversity: population versus ecosystem stability. Ecology 77:350-363. doi: 10.2307/2265614

Venail PA, MacLean RC, Bouvier T, Brockhurst MA, Hochberg ME, Mouquet N (2008) Diversity and productivity peak at intermediate dispersal rate in evolving metacommunities. Nature 452:210-215. doi:10.1038/nature06554

Wagner HH, Wildi O, Ewald KC (2000) Additive partitioning of plant species diversity in an agricultural mosaic landscape. Landscape Ecol 15:219-227. doi:

10.1023/A:1008114117913

Walker B, Kinzig A, Langridge J (1999) Plant attribute diversity, resilience, and ecosystem function: The nature and significance of dominant and minor species. Ecosystems 2:95-113. doi: 10.1007/s100219900062 WallisDeVries MF, Laca EA, Demment NW (1999) The importance of scale of patchiness for selectivity in grazing herbivores. Oecologia 121:355-363. doi: $10.1007 / \mathrm{s} 004420050939$

Wassenaar TD, van Aarde RJ, Pimm SL, Ferreira SM (2005) Community Convergence in Disturbed Subtropical Dune Forests. Ecology 86:655-666. doi: 10.1890/03-0836 
Whittaker RH (1972) Evolution and measurement of species diversity. Taxon 21:213251.

Willson MF (1993) Dispersal mode, seed shadows, and colonization patterns. Vegetatio 107/108:261-280. doi: 10.1007/BF00052229

Zobel M (1997) The relative role of species pools in determining plant species richness: an alternative explanation of species coexistence. Trends in Ecology and Evolution 12:266-269. doi:10.1016/S0169-5347(97)01096-3 
Table 1. The observed and the expected alpha, beta, and gamma diversities (based on the individual-based randomization routine) on transects within subalpine grasslands in the Central Pyrenees, Spain. In parenthesis are the 95\% Confidence Limits obtained from the individual-based randomization (Crist et al. 2003).

Observed

Expected

Individual-based

Values

Percentage

randomization

$\alpha 1 \quad 2.804$

2.797 (2.809, 2.784)

$\alpha 2 \quad 3.108$

3.266 (3.274, 3.258)

$\alpha 3 \quad 3.673$

$\beta 1 \quad 0.304$

8.3

0.469 (0.464, 0.473)

$\beta 2 \quad 0.564$

15.4

$0.408(0.400,0.415)$

$\gamma$

3.673

100

3.673 


\begin{tabular}{|c|c|c|c|}
\hline \multicolumn{4}{|c|}{$\begin{array}{l}\text { Pressure as a fixed factor, and plant richness, proportional diversity (Shannon and } \\
\text { Evenness indices), proportion (\%) of bare soil, and spatial pattern (long-range spatial } \\
\text { autocorrelation of vegetated - non-vegetated patches, DFA exponent, and Information } \\
\text { Fractal Dimension ( } \mathrm{D}_{\mathrm{I}} \text { ) as dependent variables. Analysis based on the presence of } \\
\text { species along } 36250 \text {-m linear transects in the subalpine grassland of the OMPNP, } \\
\text { Central Pyrenees, Spain, collected in } 2004 \text { and } 2005 \text {. }^{*} \mathrm{P} \leq 0.05 \text {, ** } \mathrm{P} \leq 0.01 \text {. }\end{array}$} \\
\hline Flat aspect & $\mathrm{F}(1,10)$ & $\begin{array}{c}\text { Highly Grazed } \\
\text { Mean } \pm \text { se }\end{array}$ & $\begin{array}{c}\text { Lightly Grazed } \\
\text { Mean } \pm \text { se }\end{array}$ \\
\hline Richness & 0.07 & $46 \pm 4.491$ & $45 \pm 3.266$ \\
\hline Bare soil & 0.53 & $5.466 \pm 0.780$ & $7.813 \pm 3.144$ \\
\hline Shannon & 1.73 & $2.594 \pm 0.110$ & $2.764 \pm 0.060$ \\
\hline Evenness & $8.91 * *$ & $0.678 \pm 0.013$ & $0.726 \pm 0.010$ \\
\hline $\mathrm{D}_{\mathrm{I}}$ & $4.92 *$ & $0.838 \pm 0.010$ & $0.802 \pm 0.012$ \\
\hline DFA exponent & 0.04 & $0.677 \pm 0.33$ & $0.686 \pm 0.022$ \\
\hline North aspect & $F(1,10)$ & $\begin{array}{c}\text { Highly Grazed } \\
\text { Mean } \pm \text { se }\end{array}$ & $\begin{array}{c}\text { Lightly Grazed } \\
\text { Mean } \pm \text { se }\end{array}$ \\
\hline Richness & 0.17 & $51 \pm 1.878$ & $50 \pm 2.662$ \\
\hline Bare soil & 1.06 & $4.186 \pm 0.988$ & $6.933 \pm 2.482$ \\
\hline Shannon & 0.36 & $2.753 \pm 0.074$ & $2.867 \pm 0.017$ \\
\hline Evenness & 0.70 & $0.698 \pm 0.013$ & $0.731 \pm 0.037$ \\
\hline $\mathrm{D}_{\mathrm{I}}$ & 2.79 & $0.818 \pm 0.011$ & $0.761 \pm 0.032$ \\
\hline DFA exponent & 0.8 & $0.684 \pm 0.034$ & $0.638 \pm 0.040$ \\
\hline South aspect & $F(1,10)$ & $\begin{array}{c}\text { Highly Grazed } \\
\text { Mean } \pm \text { se }\end{array}$ & $\begin{array}{c}\text { Lightly Grazed } \\
\text { Mean } \pm \text { se }\end{array}$ \\
\hline Richness & $5.04 *$ & $52 \pm 3.143$ & $33 \pm 7.757$ \\
\hline Bare soil & 0.22 & $4.426 \pm 0.610$ & $6.066 \pm 3.500$ \\
\hline Shannon & $6.40^{*}$ & $2.773 \pm 0.400$ & $1.742 \pm 0.092$ \\
\hline Evenness & $6.70^{*}$ & $0.702 \pm 0.023$ & $0.489 \pm 0.078$ \\
\hline $\mathrm{D}_{\mathrm{I}}$ & 2.33 & $0.781 \pm 0.016$ & $0.841 \pm 0.036$ \\
\hline DFA exponent & 0.16 & $0.735 \pm 0.058$ & $0.704 \pm 0.051$ \\
\hline
\end{tabular}


Table 3. Observed mean $\pm \mathrm{SE}$ and $\mathrm{F}$ values of the one-way ANOVAs with grazing pressure as a fixed factor and DFA exponent (long-range spatial auto-correlation estimator) as the dependent variable for the most abundant plant species in the subalpine grasslands flat aspect of the OMPNP in the Central Pyrenees, Spain. $* \mathrm{P}<0.05$, ** $\mathrm{P}<0.01, * * * \mathrm{P}<0.001$.

\begin{tabular}{|l|cccc}
\hline \multicolumn{1}{|c|}{ Species } & & & DFA exponent & \\
& $\mathrm{n} 2$ & $\mathrm{~F}(1, \mathrm{n} 2)$ & Highly Grazed & Lightly Grazed \\
Nardus stricta & 10 & 2.25 & $0.738 \pm 0.028$ & $0.786 \pm 0.015$ \\
Trifolium alpinum & 10 & 1.17 & $0.836 \pm 0.017$ & $0.804 \pm 0.027$ \\
Trifolium repens & 8 & $11.55^{* *}$ & $0.619 \pm 0.008$ & $0.710 \pm 0.025$ \\
Agrostis capillaris & 10 & 2.00 & $0.646 \pm 0.014$ & $0.688 \pm 0.26$ \\
Carex sp & 10 & 0.01 & $0.727 \pm 0.022$ & $0.729 \pm 0.013$ \\
Festuca rubra & 10 & 2.98 & $0.704 \pm 0.028$ & $0.758 \pm 0.014$ \\
Sanguisorba minor & 4 & 0.23 & $0.740 \pm 0.035$ & $0.680 \pm 0.016$ \\
Galium verum & 10 & $4.70^{*}$ & $0.595 \pm 0.022$ & $0.659 \pm 0.020$ \\
Achillea millefolium & 10 & $6.35 *$ & $0.619 \pm 0.018$ & $0.755 \pm 0.051$ \\
Hieracium pilosella & 8 & $13.9 * *$ & $0.632 \pm 0.030$ & $0.772 \pm 0.023$ \\
Plantago media & 9 & 0.07 & $0.667 \pm 0.024$ & $0.677 \pm 0.030$ \\
Thymus praecox & 10 & 0.94 & $0.632 \pm 0.015$ & $0.604 \pm 0.027$ \\
Lotus corniculatus & 10 & 0.15 & $0.677 \pm 0.041$ & $0.699 \pm 0.039$ \\
\hline
\end{tabular}

